\title{
ANALISIS TERHADAP SENGKETA TANAH TERKAIT PENERBITAN SERTIPIKAT HAK GUNA BANGUNAN NOMOR 2849 (STUDI KASUS PUTUSAN MAHKAMAH AGUNG NOMOR 496/K/TUN/2017)
}

\author{
Evani Sugiharto \\ (Mahasiswa Program S1 Fakultas Hukum Universitas Tarumanagara) \\ (E-mail: evanisugiharto2@gmail.com)
}

\begin{abstract}
Hasni
(Corresponding Author)

(Dosen Fakultas Hukum Universitas Tarumanagara, Meraih Sarjana Hukum dari Fakultas Hukum Universitas Atma Jaya dan Universitas Krisnadwipayana, Magister Hukum dari Fakultas Hukum Universitas Indonesia, Doktor Hukum dari Fakultas Hukum Trisakti)
\end{abstract}

\begin{abstract}
Agrarian Law is overall legal provisions, both written and unwritten, which all of that have the same set of objectsthat is as legal institutions and as a concrete legal relationship, public and private aspect, which can be arranged and studied systematically. In agrarian section, in order to deal with concrete case, granting of legal security can't be realized only with the availability of legal instruments. Land registration is required which will result certificate as a strong sign of land title. Lack of awareness in the importance of land registration activities and uncertainty over the grounds of the rights to the land owned.the problem in thiswritting ishow the implementation of Building Rights Title provition number 2849 according to the data from plaintiff and defendant over ground subject are already in accordance with legal provisions? The research method used is normative legal research method that comes from primary, secondary, and supported by interview with related experts, which is analyzed qualitatively. The result is Head of South Jakarta Land Officer who issued a Decree on Granting of Land Rights on December 5, 2013 number 991 not in accordance with the procedure in article 26 section 1 and article 28 section 1,3 Government Ordinance number 24/1997 because it has been issued 7 days prior to the end of the announcement period, so there are procedural defect in the Building Rights Title number 2849/Cilandak Barat.
\end{abstract}

Keywords: Agrarian, Land Dispute 


\section{PENDAHULUAN}

\section{A. Latar Belakang}

Tanah sebagai bagian dari bumi disebutkan dalam Pasal 4 ayat 1 Undang-Undang Nomor 5 Tahun 1960 atau yang disebut juga UndangUndang Pokok Agraria (UUPA), yaitu "Atas dasar hak menguasai dari Negara sebagai yang dimaksud dalam Pasal 2 ditentukan adanya macammacam hak atas permukaan bumi, yang disebut tanah, yang dapat diberikan kepada dan dipunyai oleh orang-orang, baik sendiri maupun bersama-sama dengan orang-orang lain serta badan-badan hukum". jelaslah bahwa tanah dalam pengertian yuridis adalah permukaan bumi, sedangkan hak atas tanah adalah hak atas sebagian tertentu permukaan bumi, yang berbatas, berdimensi dua dengan ukuran panjang dan lebar. ${ }^{1}$

Hukum Tanah adalah keseluruhan ketentuan-ketentuan hukum, baik tertulis maupun tidak tertulis, yang semuanya mempunyai obyek pengaturan yang sama yaitu hak penguasaan atas tanah sebagai lembaga-lembaga hukum dan sebagai hubungan hukum yang konkret, beraspek publik dan privat, yang dapat disusun dan dipelajari secara sistematis, hingga keseluruhannya menjadi satu kesatuan yang merupakan satu sistem. ${ }^{2}$ Obyek Hukum Tanah adalah hak penguasaan atas tanah. Yang dimaksud dengan hak penguasaan atas tanah adalah hak yang berisi serangkaian kewenangan, kewajiban dan/atau larangan bagi pemegang haknya untuk berbuat sesuatu mengenai tanah yang dimaksud. Sesuatu yang boleh, wajib atau dilarang untuk diperbuat, yang merupakan isi hak penguasan itulah yang menjadi kriteria atau tolok ukur pembeda di antara hak-hak penguasaan atas tanah yang diatur dalam Hukum Tanah. ${ }^{3}$

Dari segi asal tanahnya, hak atas tanah dibagi menjadi 2 kelompok yaitu hak primer dan sekunder. Hak-hak pengusasaan yang bersifat primer yaitu hak yang langsung diberikan oleh negara kepada pemegang haknya,

\footnotetext{
${ }^{1}$ Urip Santoso, Hukum Agraria Kajian Komprehensif (Jakarta: Kencana Prenada Media Group, 2013), hal.9.

${ }^{2}$ Ibid., $10-11$.

3 Ibid.,
} 
sedangkan hak-hak penguasaan yang bersifat sekunder yaitu hak yang timbul atau dibebankan diatas hak atas tanah yang sudah ada. Hak ini bisa timbul karena perjanjian antara pemilik tanah sebagai pemegang hak primer dan calon pemegang hak sekunder. ${ }^{4}$

Hak-hak penguasaan yang bersifat primer tersebut lahir karena pemberian hak oleh Negara sebagaimana diatur dalam Pasal 22, Pasal 31, Pasal 37, dan Pasal 41 UUPA. Penetapan Pemerintah dalam kaitannya dengan perolehan hak atas tanah adalah suatu keputusan yang diterbitkan oleh pejabat yang berwenang untuk menerbitkan hak atas tanah. Pejabat yang berwenang menerbitkan keputusan pemberian hak atas tanah adalah Kepala Badan Pertanahan Nasional Republik Indonesia (BPNRI), atau Kepala Kantor Wilayah Badan Pertanahan Nasional Provinsi, atau Kepala Kantor Pertanahan Kabupaten/Kota yang diberikan pelimpahan kewenangan untuk memberikan hak atas tanah.

Berdasarkan Pasal 4 Ayat (1) Peraturan Menteri Negara Agraria/Kepala Badan Pertanahan Nasional Nomor 9 Tahun 1999 Tentang Tata Cara Pemberian dan Pembatalan Hak Atas Tanah Negara dan Hak Pengelolaan, menentukan bahwa sebelum mengajukan permohonan hak, pemohon harus menguasai tanah yang dimohon dibuktikan dengan data yuridis dan data fisik sesuai dengan ketentuan peraturan perundang-undangan yang berlaku. Pemberian jaminan kepastian hukum di bidang pertanahan memerlukan:

1. Tersedianya perangkat hukum tertulis yang lengkap dan jelas serta dilaksananakan secara konsisten;

2. Penyelenggaraan pendaftaran tanah yang efektif.

Dengan tersedianya perangkat hukum yang tertulis, siapapun yang berkepentingan akan dengan mudah mengetahui kemungkinan apa yang tersedia baginya untuk menguasai dan menggunakan tanah yang diperlukannnya, bagaimana cara memperolehnya, hak-hak, kewajiban serta larangan-larangan apa yang ada dalam menguasai hak-hak atas tanah

${ }^{4}$ Berbagi Ilmu Hukum, "Hak Primer dan Hak Sekunder Dalam Hukum Agraria," http://elawenforcement.blogspot.com/2014/09/hak-primer-dan-hak-sekunder-dalam-hukum.html, diakses tanggal 4 Juni 2018 
tertentu, sanksi apa yang dihadapinya jika diabaikan ketentuan-ketentuan yang bersangkutan, serta hal-hal lain yang berhubungan dengan penguasaan dan penggunaan tanah yang dipunyainya.

Timbulnya sengketa hukum adalah semula dari pengaduan sesuatu pihak yang berisi keberatan-keberatan dan tuntutan hak atas tanah baik terhadap status tanah, prioritas maupun kepemilikannya dengan harapan dapat memperoleh penyelesaian secara administrasi sesuai ketentuan yang berlaku. Akan tetapi dari alasan-alasan tersebut di atas, sebenarnya tujuannya akan berakhir kepada tuntuan bahwa ia adalah yang lebih berhak dari yang lain atas tanah sengketa, oleh karena itu penyelesaian sengketa hukum terhadap sengketa tersebut tergantung dari sifat/masalah yang diajukan sehingga prosesnya akan memerlukan beberapa tahap tertentu sebelum diperoleh suatu keputusan.

Sifat permasalahan dari suatu sengketa secara umum ada beberapa macam, antara lain:

1. Masalah/persoalan yang menyangkut prioritas untuk dapat ditetapkan sebagai pemegang hak yang sah atas tanah yang berstatus hak, atau atas tanah yang belum ada haknya

2. Bantahan terhadap sesuatu alas hak/bukti perolehan yang digunakan sebagai dasar pemberian hak (perdata)

3. Kekeliruan/kesalahan pemberian hak yang disebabkan penerapan peraturan yang kurang/tidak benar

4. Sengketa/massalah kain yang mengandung aspek sosial praktis (bersifat strategis). ${ }^{5}$

Di bidang pertanahan, dalam menghadapi kasus-kasus konkret, pemberian jaminan kepastian hukum belum dapat diwujudkan hanya dengan tersedianya perangkat hukum. Sangat penting untuk memperoleh kepastian mengenai status tanahnya, siapa pemegang haknya dan ada atau tidaknya hak pihak lain. Semuanya itu diperlukan untuk mengamankan transaksi yang akan dilakukan dan mencegah timbulnya sengketa di kemudian hari.

\footnotetext{
${ }^{5}$ Rusmadi Murad, Penyelesaian Sengketa Hukum atas Tanah (Bandung: Alumni, 1991), 22.
} 
Keterangan yang dimaksudkan itu tidak mungkin diperoleh dari perangkat perundang-undangan yang tersedia. Untuk itu, diperlukan penyelenggaraan kegiatan yang disebut pendaftaran tanah yang merupakan suatu legal cadastre.

Perbuatan hukum pendaftaran tanah adalah sesuatu peristiwa penting karena menyangkut segi keperdataan seseorang. Pemerintah mempunyai kewajiban untuk mengatur pemanfaatan tanah serta menjamin kepastian hukum dan perlindungan hukum bagi pemegang hak atas tanah melalui politik hukum pertanahan di bidang pendaftaran tanah. ${ }^{6}$ Dari adanya pendaftaran tanah tersebut, maka pemegang hak atas tanah akan memperoleh sertipikat sebagai surat bukti hak untuk hak atas tanah masingmasing yang sudah dibukukan dalam buku tanah yang bersangkutan, sedangkan buku tanah merupakan dokumen dalam bentuk daftar yang memuat data fisik dan yuridis suatu obyek pendaftaran tanah yang sudah ada haknya.

Pada masa sekarang ini, sengketa pertanahan dirasakan semakin kompleks seiring dengan perkembangan reformasi yang membawa masyarakat belajar berdemokrasi dalam tatanan kehidupan berbangsa dan bernegara. Sengketa pertanahan yang semula disebabkan adanya benturan kepentingan yang berkembang antara lain berkaitan dengan:

1. nilai-nilai budaya;

2. adanya perbedaan penafsiran yang tidak sesuai dengan maksud dan tujuan UUPA yang merupakan ketentuan dasar pertanahan yang berlaku di seluruh Indonesia;

3. adanya penyimpangan dalam implementasi peraturan pelaksanaan UUPA. Kondisi ini menuntut adanya kebijakan strategis pertanahan nasional yang dapat menyelesaikan sengketa pertanahan secara lebih konseptual, komprehensif, dan terpadu. ${ }^{7}$

\footnotetext{
${ }^{6}$ Samun Ismaya, Hukum Administrasi Pertanahan (Yogyakarta: Graha Ilmu, 2013), 81.

${ }^{7}$ Pahlefi, "Analisis Bentuk-Bentuk Sengketa Hukum atas Tanah Menurut Peraturan PerundangUndangan di Bidang Agraria", Majalah Hukum Forum Akademika, Volume 25, Nomor 1 (Maret 2014): 138
} 
Pembahasan ini dipilih karena banyaknya sengketa pertanahan yang terjadi karena seringkali dalam proses pendaftaran tanah terdapat kekurangan/kelalaian yang mengakibatkan permasalahan di kemudian hari. Pendaftaran tanah yang merupakan jaminan kepastian hukum harus dilaksanakan secara konsisten sesuai dengan isi ketentuan-ketentuan hukum yang tertulis.

Sertipikat dijadikan tanda bukti hak yang kuat mengenai data fisik dan yuridis yang terdapat di dalamnya. Berdasarkan asas mutakhir dalam pendaftaran tanah yang menuntut pemeliharaan data pendaftaran tanah secara terus menerus dan berkesinambungan Dalam sengketa ini terdapat kekeliruan dalam penerbitan Sertipikat Hak Guna Bangunan Nomor 2849 yang obyek tanahnya mempunyai data fisik dan yuridis yang berbeda baik dari segi pihak Penggugat maupun Tergugat sehingga timbul permasalahan terhadap sertipikat yang diterbitkan dan juga hal ini berarti data yang tersimpan dalam Kantor Pertanahan tidak selalu sesuai dengan keadaan nyata di lapangan.

\section{B. Perumusan Masalah}

Berdasarkan latar belakang yang telah diuraikan sebelumnya, maka perumusan masalah yang dikaji adalah: "Bagaimana pelaksanaan pemberian sertipikat Hak Guna Bangunan Nomor 2849 berdasarkan data yang dimiliki oleh Penggugat maupun Tergugat atas obyek tanah, apakah telah sesuai dengan ketentuan hukum yang berlaku?"

\section{Pembahasan}

Sebagaimana yang telah dikemukakan pada latar belakang, berdasarkan Pasal 4 Ayat (1) Peraturan Menteri Negara Agraria/Kepala Badan Pertanahan Nasional Nomor 9 Tahun 1999 Tentang Tata Cara Pemberian dan Pembatalan Hak Atas Tanah Negara dan Hak Pengelolaan, menentukan bahwa sebelum mengajukan permohonan hak, pemohon harus menguasai tanah yang dimohon dibuktikan dengan data yuridis dan data 
fisik sesuai dengan ketentuan peraturan perundang-undangan yang berlaku.

Berdasarkan status tanah yang tersedia, berikut tata cara perolehan tanahnya secara singkat dalam tabel dibawah ini:

\begin{tabular}{|c|c|}
\hline $\begin{array}{l}\text { Status Tanah Yang } \\
\text { Tersedia }\end{array}$ & Tata Cara Memperolehnya \\
\hline Tanah Negara & Permohonan Hak (Pemberian Hak) \\
\hline Bagian tanah HPL & Permohonan Hak \\
\hline \multirow[t]{3}{*}{ Tanah Hak Milik } & Pemberian Hak Baru atas tanah HM \\
\hline & Pemindahan Hak (jual beli, dll) \\
\hline & $\begin{array}{l}\text { Pembebasan hak ditindak lanjuti dengan } \\
\text { permohonan hak baru yang sesuai } \\
\text { dengan keperluannya }\end{array}$ \\
\hline $\begin{array}{l}\text { Tanah HGU,HGB, } \\
\text { Hak Pakai }\end{array}$ & Pemindahan hak \\
\hline $\begin{array}{l}\text { Semua jenis hak } \\
\text { atas tanah }\end{array}$ & $\begin{array}{l}\text { Pencabutan hak ditindaklanjuti } \\
\text { dengan permohonan hak baru }\end{array}$ \\
\hline
\end{tabular}

Bagaimana cara memperoleh tanahnya tergantung pada status tanah yang tersedia, jika tanah yang tersedia tanah Negara atau tanah Hak Pengelolaan dapat diperoleh melalui tata cara permohonan hak dan apabila memenuhi persyaratan yang ditetapkan dapat ditindak lanjuti dengan pemberian hak sebagaimana diatur dalam Permen Agraria Nomor 9 Tahun 1999.

Jika tanah yang tersedia tanah hak dapat digunakan lebih dari satu cara. Apabila yang bersedia tanah Hak Milik, pemilik tanah dapat memberikan hak baru kepada pihak lain sebagai pemegang hak baru. Hak baru yang dapat diberikan atas tanah non pertanian di perkotaan adalah HGB, Hak Pakai, Hak Sewa (dalam Pasal 44 UUPA: Hak Sewa Bangunan) dan di pedesaan Hak Gadai, Hak Usaha Bagi Hasil, Hak Menumpang dan Hak Sewa atas tanah pertanian. Dipihak lain, apabila 
yang tersedia tanah hak lainnya yang bersatus Hak Milik, HGU, HGB dan Hak Pakai, dapat diperoleh melalui pemindahan hak misalnya dalam bentuk jual beli tanah, tukar menukar, hibah, pemasukan dalam perusahaan dan lainnya.

Hak atas tanah yang diperoleh karena pemberian hak "lahir" (terjadi) secara yuridis pada saat dibuatkan Buku Tanah hak yang bersangkutan (pendaftaran pertama kali), yaitu dicatat jenis haknya dan nama pemegang haknya. Tanpa pendaftaran tanah, maka hak tersebut tidak akan lahir.

Kegiatan pendaftaran tanah diatur dalam PP Nomor 24//1997 yang dimana pada Pasal 1 butir 1 menyatakan, pendaftaran tanah adalah rangkaian kegiatan yang dilakukan oleh Pemerintah secara terus menerus, berke-sinambungan dan teratur, meliputi pengumpulan, pengolahan, pembukuan, dan penyajian serta pemeliharaan data fisik dan data yuridis, dalam bentuk peta dan daftar, mengenai bidang-bidang tanah dan satuansatuan rumah susun, termasuk pemberian surat tanda bukti haknya bagi bidang-bidang tanah yang sudah ada haknya dan hak milik atas satuan rumah susun serta hak-hak tertentu yang membebaninya.

Penyelenggaraan pendaftaran tanah dalam masyarakat modern merupakan tugas Negara yang dilaksanakan oleh Pemerintah bagi kepentingan rakyat, dalam rangka memberikan jaminan kepastian hukum di bidang pertanahan. Sebagian kegiatannya yang berupa pengumpulan data fisik tanah yang haknya didaftar, dapat ditugaskan kepada swasta. Tetapi untuk memperoleh kekuatan hukum, hasilnya memerlukan pengesahan Pejabat Pendaftaran yang berwenang, karena akan digunakan sebagai data bukti. ${ }^{8}$

Ada dua macam sistem pendaftaran tanah, yaitu sistem pendaftaran akta (registration of deeds) dan sistem pendaftaran hak (registration of titles). Sistem pendaftaran tanah mempermasalahkan: apa yang didaftar, bentuk penyimpanan dan penyajian data yuridisnya serta bentuk tanda bukti haknya. Sistem yang dianut oleh PP 24/1997 adalah sistem

\footnotetext{
${ }^{8}$ Boedi Harsono, Hukum Agraria Indonesia (Jakarta: Universitas Trisaksi, 2016), 72.
} 
pendaftaran hak (registration of titles) sebagaimana yang digunakan dalam PP 10/1961. Hal ini terlihat dengan adanya Buku Tanah (register) sebagai dokumen yang memuat data yuridis dan data fisik yang dihimpun dan disajikan, serta diterbitkannya sertipikat sebagai tanda hak yang didaftar.

Baik dalam sistem pendaftaran akta maupun sistem pendaftaran hak, tiap pemberian atau menciptakan hak baru serta pemindahan dan pembebananya dengan hak lain kemudian, harus dibuktikan dengan suatu akta. Dalam sistem pendaftaran hak juga setiap penciptaan hak baru dan perbuatan-perbuatan hukum yang menimbulkan perubahan kemudian, juga harus dibuktikan dengan suatu akta. Tetapi dalam penyelenggaraaan pendaftarannya, bukan aktanya yang didaftar, melainkan haknya yang diciptakan dan perubahan-perubahannya kemudian. Akta hanya merupakan sumber datanya.

Untuk pendaftaran hak dan perubahan-perubahan yang terjadi, kemudian disediakan suatu daftar isian atau yang disebut buku tanah. Jika terjadi perubahan, tidak dibuatkan buku tanah baru, melainkan dilakukan pencatatannya pada ruang mutasi yang disediakan pada buku tanah yang bersangkutan. Sebelum dilakukannya pendaftaran haknya dalam buku tanah dan pencatatan perubahannya kemudian, oleh Pejabat Pendaftaran Tanah (PPT) dilakukan pengujian kbenaran data yang dimuat dalam akta yang bersangkutan. Sebagai tanda-tanda bukti hak, diterbitkan sertipikat yang merupakan salinan register. Sertipikat hak atas tanah tediri atas salinan buku tanah dan surat ukur yang dijilid menjadi satu dalam sampul dokumen. ${ }^{9}$

Data yang disimpan/disajikan, baik data fisik maupun data yuridis, perlu disesuaikan dengan perubahan-perubahan yang terjadi kemudian, agar selalu sesuai dengan keadaan yang sebenarnya. Inilah yang disebut kegiatan pemeliharaan data. Perubahan pada data fisik terjadi jika luas tanahnya berubah yaitu jika terjadi pemisahan atau pemecahan bidang tanah yang bersangkutan menjadi satuan-satuan baru atau penggabungan

9 Ibid., 
bidang-bidang tanah yang berbatasan menjadi satu satuan persil. Perubahan tersebut diikuti dengan pencatatan pada peta pendaftaran dan pembuatan surat atau surat-surat ukur baru. Perubahan pada data yuridis bisa mengenai haknya, yaitu berakhir jangka waktu berlakunya, dibatalkan, dicabut atau dibebani hak lain. Perubahan juga bisa mengenai pemegang haknya, yaitu jika terjadi pewarisan, pemindahan hak, atau penggantian nama. Dalam sistem pendaftaran akta untuk perubahanperubahan itu dibuatkan akta, yang selanjutnya merupakan surat tanda buktinya. Dalam sistem pendaftaran hak perubahannya dicatat pada buku tanah dan sertipikat hak yang bersangkutan, berdasarkan data yang dimuat dalam akta perubahannya.

Macam-macam jenis pemeliharaan data:

1. Pemeliharaan data karena pemindahan hak yang tidak melalui lelang

2. Pemeliharaan data karena pemindahan hak melalui lelang

3. Pemeliharaan data disebabkan peralihan hak kerena warisan

4. Pemeliharaan data disebabkan peralihan hak karena penggabungan atau peleburan perseroan atau koperasi

5. Pemeliharaan data karena pembebanan hak

6. Penolakan pendaftaran peralihan dan pembebanan hak

7. Pemeliharaan data karena perpanjangan jangka waktu hak atas tanah

8. Pemeliharaan data karena pemecahan, pemisahan dan penggabungan bidang tanah

9. Pemeliharaan data karena hapusnya hak atas tanah, Hak Pengelolaan dan Hak Milik Atas Satuan Rumah Susun

10. Pemeliharaan data karena peralihan dan hapusnya Hak Tanggungan

11. Pemeliharaan data karena perubahan nama

12. Pemeliharaan data berdasarkan Putusan atau Penetapan Ketua Pengadilan

13. Pemeliharaan data sehubungan dengan perubahan hak atas tanah.

Manfaat Sertipikat hak atas tanah bagi pemegang hak yaitu memberikan rasa aman, dapat mengetahui dengan jelas data fisik dan data 
yuridisnya, memudahkan dalam pelaksanaan peralihan hak, harga tanah menjadi lebih tinggi, dapat dijadikan jaminan hutang dengan dibebani Hak Tanggungan, penetapan Pajak Bumi dan Bangunan (PBB) tidak mudah keliru; sedangkan manfaat bagi Pemerintah yaitu terwujudnya tertib administrasi pertanahan sebagai salah satu program Catur Tertib Pertanahan, dapat memperlancar kegiatan Pemerintah yang berkaitan dengan tanah dalam pembangunan, dapat mengurangi sengketa di bidang pertanahan, misalnya sengketa batas-batas tanah, pendudukan tanah liar. Kemudia manfaat bagi calon pembeli atau kreditur adalah dapat dengan mudah memperoleh keterangan yang jelas mengenai data fisik dan data yuridis tanah yang akan menjadi obyek perbuatan hukum mengenai tanah. $^{10}$

Sertipikat hak atas tanah merupakan produk hukum Pejabat Tata Usaha Negara (TUN), pejabat yang dimaksudkan adalah Kepala Kantor Pertanahan Kabupaten/Kota, Panitia Ajudikasi dan Pejabat yang mendapat pelimpahan wewenang dari Kepala Kantor Pertanahan Kabupaten/Kota, maka produk hukum yang dikeluarkan oleh Pejabat yang berwenang berlaku ketentuan Hukum Administrasi Negara, artinya: "seseorang selaku pejabat TUN dapat saja melakukan perbuatan yang terlingkup sebagai perbuatan yang melawan hukum baik karena kesalahan (schuld) maupun akibat kelalaian menjalankan kewajiban hukumnya. ${ }^{11}$

Perbuatan hukum administrasi yang mengandung kekeliruan bentuknua bermacam-macam, yang dapat digolongkan sebagai berikut:

1. Perbuatan hukum dilakukan dibawah wewenangnya, akan tetapi tidak mengindahkan cara-cara atau bentuk-bentuk yang ditentukan oleh peraturan/ketentuan dasarnya (prosedural)

Ibid.,

11 Syafruddin Kalo, "Aspek dan Impikasi Hukum Dalam Pendaftaran Tanah dan Penertiban Sertipikat atas Tanah,” http://www.hukumonline.com/berita/baca/hol19216/aspek-dan-implikasihukum-dalam-pendaftaran-tanah-dan-penertiban-sertifikat-hakhak-atas-tanah, diakses tanggal 4 Juni 2018 
2. Perbuatan hukum tersebut isinya bertentangan dengan hukum/melanggar moral/etika/tata susila

3. Keputusan yang diambul mengandung unsur-unsur paksaan, penipuan, kekhilafan serta pengaruh negatif dari pihak ketiga

4. Perbuatan hukum tersebut dilakukan dibawah wewenangan dan menurut prosedur akan tetapi hanya memutuskan sebagian saja dari seluruh permasalahan

5. Perbuatan hukum ditambah syarat yang secara nyata bukan termasuk wewenangnya (detournement depouvoir)

6. Perbuatan hukum yang dilakukan oleh organ administrasi tersebut tidak jelas wewenangnya, baik mengenai materi atau urusan yang diputuskan

Atas perbuatan yang salah atau lalai tadi menghasilkan produk hukum sertipikat yang salah, baik kesalahan atas subyek hukum dalam sertipikat maupun kesalahan atas hukum dalam sertipikat tersebut. Kesalahan mana telah ditengarai dapat terjadi dalam berbagai proses pendaftaran tanah. Pendaftaran tanah dengan sistem publikasi negatif, perlu dimengerti dan dipahami, bahwa sertipikat hak atas tanah masih dapat dibatalkan apabila:

1. dalam proses penerbitannya mengandung unsur cacat hukum administrasi;

2. karena putusan pengadilan yang sudah memperoleh ketetapan hukum tetap.

Bahwa pemegang sertipikat masih dimungkinkan untuk digugat oleh pihak-pihak yang merasa berhak atas tanah tersebut, dan apabila pihak yang merasa berhak dapat membuktikan sebaliknya dengan alat bukti lain, dan di- menangkan dalam proses pengadilan serta telah memperoleh putusan yang telah berketetapan hukum tetap. ${ }^{12}$

Pembatalan sertipikat hak atas tanah diatur dalam Pasal 107 Peraturan No. 9 Tahun 1999:

\footnotetext{
${ }^{12}$ Bronto Susanto, et. al.,"Kepastian Hukum Sertipikat Hak Atas Tanah Berdasarkan Peraturan Pemerintah Nomor 24, “ DIH Jurnal Ilmu Hukum , Volume 10, Nomor 20 (Agustus 2014): 78, diakses tanggal 4 Juni 2018, doi: jurnal.untag-sby.ac.id/index.php/dih/article/download/359/308
} 
1. Pembatalan sertipikat hak atas tanah karena cacat hukum administratif, disebabkan oleh:

a) Kesalahan prosedur

b) Kesalahan penerapan peraturan perundang-undangan

c) Kesalahan subyek hak

d) Kesalahan objek hak

e) Kesalahan jenis hak

f) Kesalahan perhitungan luas

g) Terdapat tumpang tindih hak atas tanah

h) Data yuridis atau data fisik tidak benar, atau

i) kesalahan lainnya yang bersifat hukum administratif.

2. Pembatalan sertipikat hak atas tanah karena putusan pengadilan yang sudah memperoleh ketetapan hukum tetap, artinya: "pembatalan hak atas tanah karena melaksanakan putusan pengadilan yang telah memperoleh kekuatan hukum tetap diterbitkan atas permohonan yang berkepentingan, di- mana permohonan tersebut diajukan langsung kepada Menteri atau Kepala Kantor Wilayah atau melalui Kantor Pertanahan $^{13}$

Sertipikat hak atas tanah dapat dibatalkan, karena sangat dipengaruhi oleh sistem publikasi pendaftaran tanah yang dianut PP No. 24 Tahun 1997 adalah sistem publikasi negatif bertendensi positif, artinya: "suratsurat tanda bukti hak (sertipikat) yang berlaku sebagai alat pembuktian yang kuat. ${ }^{14}$

Dalam sengketa tanah pada Putusan Nomor 158/G/2016/PTUN-JKT yang menjadi objek gugatan adalah Sertipikat Hak Guna Bangunan Nomor 2849/Cilandak Barat yang diterbitkan pada tanggal 30 Desember 2015 terakhir tercatat atas nama Dewi Gayatri, obyek tanahnya adalah tanah seluas $290 \mathrm{~m}^{2}$ (dua ratur sembilan puluh meter persegi) yang terletak di Jalan Cilandak Bawah RT 10 RW 13 (dahulu RW 01).

${ }^{13}$ Syafruddin Kalo, Loc.Cit.

${ }^{14}$ Syafruddin Kalo, Loc.Cit. 
Berikut merupakan kronologis perolehan obyek tanah dari Penggugat (Yana Heriyana) berdasarkan alat bukti yang dilampirkan dalam Putusan Nomor 158/G/2016/PTUN-JKT:

1. Tanggal 24 November 1992, Kwitansi Pembayaran Tanah Hak Garapan Milik Eddy Korompis yang telah diterima dari Ny. Aty Setiawaty

2. Tanggal 7 Desember 1992, Kwitansi Pembayaran Tanah Hak Garapan Milik Eddy Korompis yang telah diterima dari Ny. Aty Setiawaty

3. Tanggal 15 Februari 1993, Kwitansi Pembayaran Tanah Hak Garapan Milik Eddy Korompis yang telah diterima dari Ny. Aty Setiawaty

4. Tanggal 31 July 2012, Grosse Akta Nomor 5 Perihal Pengoperan dan Penyerahan Hak antara Ny. Aty Setiawaty kepada Yana Heriyana Rochiman (Penggugat) dibuat dihadapan Surdjono Arham.,SH.,MKn, Notaris di Jakarta

Berikut merupakan kronologis perolehan obyek tanah dari Tergugat Intervensi II (Dewi Gayatri) berdasarkan alat bukti yang dilampirkan dalam Putusan Nomor 158/G/2016/PTUN-JKT:

1. Tanggal 19 September 1970, Surat Jual Beli Sementara Tanah Kavling Yayasan Industri antara Drs. Rachmat Ali kepada Ir. Chamrul Djafri

2. Tanggal 5 November 2012, Surat Perjanjian Jual Beli Tanah antara Ir. Chamrul Djafri kepada Bambang Pramushinto

3. Tanggal 22 Februari 2013, Akta Pelepasan Hak Atas Tanah antara Ir. Chamrul Djafri kepada Bambang Pramushinto dibuat dihadapan Fitriani SH pengganti Raden Johanes Sarwono

4. Tanggal 19 Januari 2016, Akta Jual Beli Nomor 12 antara Bambang Pramushinto dengan Dewi Gayatri (Tergugat Intervensi II) dibuat dihadapan Laurensia Siti Nyoman., SH Notaris di Jakarta

Obyek tanah telah dikuasai secara fisik oleh Penggugat (Yana Heriyana) dengan bukti adanya pagar yang telah dibangun sejak tahun 1992 oleh pemilik sebelumnya yaitu Ny. Aty Setiawaty yang merupakan istri dari Ibrahin Harisnanto Soetopo. Lokasi bidang tanah yang dimiliki 
Penggugat dengan bidang tanah sengketa berada dalam satu lokasi bidang tanah.

Obyek sengketa tersebut sebelumnya telah diajukan di Pengadilan Tata Usaha Negara Jakarta dalam Putusan 58/G/2014/PTUN-JKT jo. Putusan Pengadilan Tinggi Tata Usaha Negara Jakarta 63/B/2015/PT.TUN.JKT yang diajukan oleh Putri Intan Sari sebagai Penggugat terhadap Tergugat (Ka Kan Pertanahan Jakarta Selatan), telah juga diajukan di Pengadilan Negeri Jakarta dengan Nomor 146/Pdt.G/2015/PN.Jkt.Sel antara Tando Aburdin sebagai Penggugat terhadap Tergugat. Putusan yang dijatuhkan oleh majelis hakim dalam perkara-perkara tersebut bersifat negatif yaitu menyatakan gugatan tidak dapat diterima.

Menurut keterangan saksi dalam Putusan 58/G/2014/PTUN-JKT sebelumnya pernah terjadi pertemuan antara Bambang Pramushinto, Ir. Chamroel Djafri dan Ibrahim Harisnantio Soetopo, pernah terjadi mediasi antara Bambang Pramushinto dengan Yana Heriyana yang tidak menemukan titik temu dan Ir. Charoel Djafri pernah menggugat Ibrahim Harisnanto Soetopo. Kemudian sebelum tanah tersebut dijual kepada Putri Intan Sari terdapat upaya penyelesaian masalah di kelurahan yang dihadiri oleh Bambang Pramushinto, Ibrahim Harisnantio dan Yana Heriyana.

Kronologis perolehan tanah baik dari Penggugat maupun Tergugat Intervensi II tidak diketahui dengan jelas bagaimana Eddy Korompis bisa melakukan transaksi atas obyek tanah tersebut kepada Ny. Aty karena tidak diketahui bukti kepemilikan atas tanah yang ia punya.

Menurut Penjelasan Keputusan Kepala Badan Pertanahan Nasional (BPN) Nomor 2 Tahun 2003 tentang Norma dan Standar Mekanisme Ketatalaksanaan Kewenangan Pemerintah di Bidang Pertanahan yang Dilaksanakan oleh Pemerintah Kabupaten/Kota, yaitu tanah garapan adalah sebidang tanah yang sudah atau belum dilekati dengan sesuatu hak yang dikerjakan dan dimanfaatkan oleh pihak lain baik dengan persetujuan atau tanpa persetujuan yang berhak dengan atau tanpa jangka waktu tertentu. Ny. Aty mendapatkan tanah tersebut tanpa alas hak yang sah dan 
hanya berdasarkan Surat Penyataan dari Eddy Korompis dengan Ny. Aty Setiawaty tertanggal 1 Desember 1992, sehingga sampai sekarang tanah tersebut tidak bersertifikat karena tidak ada alas haknya.

Pada dasarnya Tanah Garapan itu tidak bisa diperjualbelikan karena masih merupakan tanah negara, namun Tanah garapan dapat dialihkan/dioper hak atas garapan yang melekat padanya kepada pihak lain. Dalam Pasal 13 Ayat (3) Keputusan Menteri Agraria Nomor 21 Tahun 1994 sendiri ditentukan bahwa Tanah Negara yang dipakai oleh pihak ketiga pada dasarnya dapat diperoleh untuk disertifikasi menjadi hak-hak atas tanah yang baru.

Hal ini menandakan Peraturan Perundang-undangan sebenarnya memperbolehkan dilakukannya peralihan terhadap tanah garapan. Memiliki tanah garapan berarti mempunyai hak untuk menempati, memakai dan menikmati. Untuk objek tanah garapan, akta atau perjanjian yang dibuat untuk suatu peralihan hak yaitu akta pengoperan hak atas tanah. Kemudian, apabila ada bangunan yang berdiri di atas tanah dan turut dialihkan, maka akta yang dibuat adalah akta jual beli bangunan dan pengoperan hak. Bukti peralihannya adalah akta tersebut, bukan kwitansi. Perlu diketahui di sini bahwa kwitansi diberikan bukan karena jual beli, melainkan karena pembayaran atas pengoperan hak. Dengan adanya akta pengoperan hak, maka peralihan hak penguasaan atas tanah garapan adalah sah menurut hukum.

Dalam putusan ini dilampirkan tanda bukti berupa Grosse Akta Nomor 5 tanggal 31 Juli 2012 Perihal Pengoperan dan Penyerahan Hak, antara Ny Aty Setiawaty dan Yana Heriyana (Penggugat), seharusnya dengan adanya Akta Pengoperan dan Penyerahan Hak ini, peralihan hak penguasaan atas tanah garapan adalah sah. Namun obyek tanah tersebut sebelum terdapat Surat Keputusan Kepala Kantor Pertanahan Kota Administrasi Jakarta Selatan Nomor 991 tanggal 5 Desember 2013 atas nama Bambang Pramushinto tidak terdapat alas haknya. Tidak adanya alas hak ini memicu terjadinya sengketa pertanahan dalam putusan ini. 
Tanah yang sudah didapatkan berdasarkan hasil peralihan hak baik secara jual beli, hibah, waris dan lainnya maupun dari hasil permohonan hak harus segera didaftarkan agar mendapatkan tanda bukti hak berupa sertipikat. Pendaftaran tanah yang bertujuan memberikan jaminan kepastian hukum disebut juga dengan recht cadaster/legal cadaster. Jaminan kepastian hukum yang hendak diwujudkan dalam pendaftaran tanah, meliputi kepastian status hak yang didaftar, kepastian subyek hak dan kepastian obyek hak. Pendaftaran tanah ini menjadi kewajiban bagi Pemerintah maupun pemegang hak atas tanah. Ketentuan Pasal 19 UUPA menjadi dasar pembentukan PP Nomor 10 Tahun 1961 tentang Pendaftaran Tanah yang kemudian diganti menjadi PP Nomor 24 Tahun 1997.

Berdasarkan ketentuan tersebut penerbitan Sertipikat Hak Guna Bangunan Nomor 2849/Cilandak Barat yang diterbitkan berdasarkan Surat Ukur Nomor 00296/Cilandak Barat/2013 tidak sepenuhnya sesuai dengan ketentuan mengenai pendaftaran tanah yang berlaku. Dalam Pasal 30 dan 31 PP Nomor 24 Tahun 1997 dinyatakan apabila di dalam buku tanah terdapat catatan yang menyangkut data fisik dan yuridisnya belum lengkap maupun yang data fisik dan yuridisnya dipersengketakan mewajibkan Tergugat untuk melakukan pencatatan dalam buku tanah apabila terdapat sengketa, sebelum catatan mengenai sengketa tersebut dihapus maka Tergugat wajib untuk menangguhkan penerbitan sertipikat.

Menurut pendapat dari Ibu Endang Pandamdari, kesalahan dalam pencatatan di Buku Tanah bisa terjadi karena kekeliruan dari Pihak BPN dalam pencatatan terkait nama pemilik atau terdapat pihak yang mengaku sebagai pemilik suatu tanah. Pihak yang mengakui suatu tanah sebagai miliknya tersebut melakukan pendaftaran, kemudian Pihak BPN tidak menelusuri lebih lanjut mengenai pengecekan data materil atau data praktek terkait tanah yang dimaksud.

Dalam pendaftaran tanah juga terdapat asas kontradiktur delimitasi yang merupakan asas yang mewajibkan pemegang hak atas tanah untuk 
memperhatikan penempatan, penetapan dan pemeliharaan batas tanah secara kontradiktur atau berdasarkan kesepakatan dan persetujuan pihakpihak yang berkepentingan, yang dalam hal ini adalah pemilik tanah yang berbatasan dengan tanah yang dimilikinya.

Hal ini seperti yang disampaikan oleh Bapak Hanafi Tanawijaya dimana dalam hal pengukuran tanah wajib dilakukan secara musyawarah dan mufakat dengan orang-orang yang tanahnya saling berbatasan langsung, inilah yang dinamakan asas kontradiktur delimitasi. Sehingga apabila asas ini tidak terpenuhi maka hasil pengukuran tanah bisa dibatalkan, hasil pengukuran tanah diumumkan selama 60 hari untuk memberi kesempatan bagi para pihak untuk mengajukan keberatan. Asas kontradiktur delimitasi ini terdapat pada Pasal 17 sampai Pasal 19 PP Nomor 24 Tahun 1997 yang dapat penulis simpulkan bahwa dalam penetapan batas bidang tanah pada pendaftaran tanah diupayakan pemetaan batas berdasarkan kesepakatan para pihak yang berkepentingan, penempatan tanda-tanda batas termasuk pemeliharaannya wajib dilakukan oleh pemegang hak atas tanah yang bersangkutan, jika dalam penetapan batas bidang tanah tidak diperoleh kesepakatan antara pemegang hak atas tanah yang bersangkutan dengan pemegang hak atas tanah yang berbatasan, maka pengukuran bidang tanahnya diupayakan untuk sementara dilakukan berdasarkan batas-batas yang menurut kenyataannya merupakan batas-batas bidang tanah yang bersangkutan.

Obyek sengketa merupakan pendaftaran tanah untuk pertama kalinya yang dilaksanakan atas permintaan Bambang Pramushinto sebagai pihak yang berkepentingan, maka pendaftaran tanah demikian merupakan pendaftaran tanah secara sporadik berdasarkan ketentuan Pasal 13 PP Nomor 24 Tahun 1997.

Data isian hasil penelitian alat-alat bukti beserta peta bidang-bidang tanah yang bersangkutan harus diumumkan selama 60 (enam puluh) hari berdasarkan Pasal 26 PP Nomor 24 Tahun 1997 untuk memberi kesempatan kepada pihak yang berkepentingan mengajukan keberatan, 
pengumuman dapat dilakukan di Kantor Pertanahan dan Kantor Kepala Desa/ Kelurahan letak tanah yang bersangkutan dalam pendaftaran tanah secara sporadik.

Berdasarkan Pasal 27 PP Nomor 24 Tahun 1997, apabila ada yang mengajukan keberatan terhadap hasil pengukuran maka Kepala Kantor Pertanahan mengusahakan agar secepatnya keberatan yang diajukan diselesaikan secara musyawarah untuk mufakat dan jika tidak membawa hasil, Kepala Kantor Pertanahan mem beritahukan secara tertulis kepada pihak yang mengajukan keberatan agar data fisik dan atau data fisik dapat dipersengketakan di pengadilan.

Pada saat permohonan pendaftaran hak oleh Bambang Pramushinto belum dilakukan upaya penyelesaiannya baik melalui musyawarah untuk mufakat maupun melalui pengadilan, sehingga hal ini tidak sesuai dengan ketentuan Pasal 26 Ayat 1 PP Nomor 24 Tahun 1997 yang menyatakan jika dalam jangka waktu pengumuman hasil pengukuran ada yang mengajukan keberatan terkait data fisik dan atau data yuridis yang diumumkan maka Ka Kan Pertanahan dalam pendaftaran tanah secara sporadik mengusahakan secepatnya agar keberatan yang diajukan diselesaikan secara musyawarah untuk mufakat.

Permohonan pendaftaran tanah Bambang Pramushinto telah dilakukan proses pengukuran dan telah pula dituangkan dalam bentuk surat ukur pada tanggal 9 Oktober 2013 dan Surat Keputusan Ka Kan Pertanahan Kota Administratif Jakarta Selatan tentang pemberian Hak Guna Bangunan kepada pemohon hak atas tanah dikeluarkan pada tanggal 5 Desember 2013, dapat dilihat bahwa surat ukur yang dimaksud dikeluarkan pada tanggal 9 Oktober 2013 dan tanggal dikeluarkannya Surat Keputusan pada tanggal 5 Desember 2013.

Apabila berdasarkan Pasal 26 Ayat 1 PP Nomor 24 Tahun 1997 yang mengharuskan Tergugat (BPN) untuk mengumumkan selama 60 hari, sehingga apabila perhitungan tenggang waktu pengumuman dihitung setelah tanggal terbitnya surat ukur dan dan pengumpulan penelitian 
kebenaran data yuridis yaitu tanggal 11 Oktober 2013 maka akan diperoleh tanggal berakhirnya pengumuman yaitu tanggal 9 Desember 2013. Yang dimaksud dalam pengumuman ini adalah dalam pendaftaran tanah sporadik, sedangkan apabila dalam pendaftaran tanah sistematik selama 30 hari. Hal yang diumumkan pada dasarnya adalah data fisik dan data yuridis. Pengumuman pendaftaran tanah secara sporadik sifatnya individual dengan ruang lingkup terbatas.

Setelah itu pada tanggal 10 Desember 2013 Ka Kan Pertanahan melakukan pengesahan dengan suatu berita acara yang bentuknya ditetapkan oleh Menteri dan berita acara pengesahan tersebut menjadi dasar untuk pemberian hak atas tanah artinya keputusan pemberian hak atas tanah baru akan dikeluarkan oleh tergugat paling cepat setidaktidaknya pada tanggal 11 Desember 2013 atau tanggal 22 Desember 2013. Belum lengkapnya data yang tersedia atau masih adanya keberatan yang tidak dapat diselesaikan secara musyawarah untuk mufakat, bukan merupakan alasan menunda dilakukannya pembuatan berita acara hasil pengumuman data fisik dan data yuridis.

Pemberian Hak atas Tanah yang diterbitkan pada tanggal 5 Desember 2013 Nomor 991 tidak sesuai dengan prosedur Pasal 26 Ayat 1 jo. Pasal 28 Ayat 1 dan Ayat 3 huruf C PP Nomor 24 Tahun 1997 karena telah diterbitkan lebih cepat 7 hari sebelum masa pengumuman berakhir sehingga pada obyek sengketa dalam putusan ini terdapat cacat prosedural. Berdasarkan hal tersebut juga berarti kesempatan bagi pihak yang berkepentingan untuk mengajukan keberatan dimulai sejak tanggal 11 Oktober sampai dengan tanggal 9 Desember 2013.

Obyek sengketa yang berupa Sertipikat Hak Guna Bangunan dalam sengketa ini diterbitkan pada tanggal 30 Desember 2015, ketentuan Pasal 32 Ayat PP Nomor 24 Tahun 1997 memperbolehkan pihak yang merasa kepentingannya dirugikan dapat menuntut pelaksanaan hak tersebut dalam jangka waktu 5 tahun setelah sertipikat itu diterbitkan. Ketentuan ini bertujuan pada para pihak agar memberikan kepastian hukum kepada 
pihak, yang dengan itikad baik menguasai sebidang tanah dan didaftar sebagai pemegang hak dalam buku tanah, karena selama tidak adanya ketentuan ini, suatu tanah bisa di gugat kapanpun.

Sistem publikasi yang digunakan dalam Hukum Tanah Nasional yaitu sistem negatif yang mengandung unsur positif, karena akan menghasilkan surat-surat tanda bukti hak yang berlaku sebagai alat pembuktian yang kuat. Sistem publikasi negatif murni tidak akan menggunakan sistem pendaftaran hak dan juga tidak akan ada pernyataan bahwa sertipikat merupakan alat bukti yang kuat.

Karena sistem publikasi negatif pihak yang nama-nya tercantum sebagai pemegang hak dalam buku tanah dan sertipikat selalu menghadapi kemungkinan gugatan dari pihak lain yang merasa mempunyai tanah itu. Dalam hukum adat terdapat lembaga yang dapat digunakan untuk mengatasi kelemahan sistem publikasi negatif dalam pendaftaran tanah, yaitu lembaga rechtsverwerking. Dalam hukum adat jika seseorang membiarkan tanahnya tidak dikerjakan, kemudian tanah itu digunakan orang lain yang memperolehnya dengan itikad baik, maka hilanglah haknya untuk menuntut kembali tanah tersebut.

Pada sengketa ini Tergugat hanya mengajukan bukti berupa Buku Tanah Hak Guna Bangunan Nomor 02849/Cilandak Barat seluas 400m² terakhir tercatat atas nama Nyonya Dewi Gayatri dan Akta Jual Beli Nomor 12/2016 tanggal 19 Januari 2016. Bukti-bukti yang diajukan Tergugat selaku Ka Kan Pertanahan sangat minim sedangkan kewenangan memproses permohonan pendaftaran hak atas tanah ada pada Tergugat berikut bukti permohonan, data yuridis, data fisik dan dokumen-dokumen sebagai bukti pelaksanaan prosedur pendaftaran tanah oleh Tergugat telah dijalankan dengan semestinya sesuai ketentuan peraturan perundangundangan pendaftaran tanah.

Berdasarkan Pasal 35 PP Nomor 24 Tahun 1997, buku tanah harus tetap berada di Kantor Pertanahan tetapi atas perintah pengadilan dapat dibawa oleh Ka Kan Pertanahan yang bersangkutan atau Pejabat yang 
ditunjuknya ke sidang pengadilan tersebut untuk diperlihatkan kepada Majelis Hakim dan para pihak yang bersangkutan.

Dari uraian diatas dan berdasarkan referensi bacaan dari internet yang penulis baca, Akta Pengoperan Hak memang tidak diatur di dalam undangundang, tetapi ada beberapa notaris yang membuat akta tersebut berdasarkan jual beli atas tanah garapan. Salah satu contoh notaris yang membuat akta ini adalah Surdjono Arham yang membuat Akta Pengoperan dan Penyerahan Hak antara Ny. Aty Setiawaty dengan Penggugat. Tanah garapan peningkatan hak, masih diperlukan proses sertifikat sebelum dilakukan proses perizinan lebih lanjut. Akta Pengoperan Hak ini dalam lapangan dibuat apabila yang menjadi obyek jual beli merupakan tanah garapan, tanah garapan ini biasanya masih belum ada alas haknya sehingga dapat menimbulkan ketidakjelasan dalam kegiatan pemeliharaan data pendaftaran tanah. Namun karena tanah garapan bukan merupakan obyek tanah yang sudah terdaftar, pihak lain dapat mengklaim mengenai status kepemilikan atas tanah tersebut. Pihak Tergugat Intervensi yaitu Dewi Gayatri tidak salah dalam pengakuannya atas obyek tanah tersebut, karena obyek tanah tersebut yang merupakan obyek garapan yang sebelumnya belum dilekati hak apapun, maka kemudian oleh Bambang Pramushinto dilakukan proses pendaftaran tanah atas obyek tersebut.

Tetapi karena dalam proses pendaftaran tanah terkait sertipikat Hak Guna Bangunan yang diterbitkan terdapat cacat prosedural mengenai perhitungan tenggang waktu pengumuman dihitung setelah tanggal terbitnya surat ukur dan dan pengumpulan penelitian kebenaran data yuridis yaitu tanggal 11 Oktober 2013 maka akan diperoleh tanggal berakhirnya pengumuman yaitu tanggal 9 Desember 2013 sehingga seharusnya keputusan pemberian hak atas tanah baru akan dikeluarkan oleh tergugat paling cepat setidak-tidaknya pada tanggal 11 Desember 2013 atau tanggal 22 Desember 2013.

Pemberian Hak atas Tanah yang diterbitkan pada tanggal 5 Desember 2013 Nomor 991 telah tidak sesuai dengan prosedur Pasal 26 Ayat 1 jo. 
Pasal 28 Ayat 1 dan Ayat 3 huruf C PP Nomor 24 Tahun 1997 karena telah diterbitkan lebih cepat 7 hari sebelum masa pengumuman berakhir sehingga pada obyek sengketa ddalam putusan ini terdapat cacat prosedural. Berdasarkan hal tersebut juga berarti kesempatan bagi pihak yang berkepentingan untuk mengajukan keberatan dimulai sejak tanggal 11 Oktober sampai dengan tanggal 9 Desember 2013.

Keputusan Hakim untuk membatalkan sertipikat Hak Guna Bangunan Nomor 2849 ini sudah benar, namun mengenai status akan tanah ini sendiri sebaiknya dilakukan proses yang lebih lanjut dengan mengajukan gugatan keperdataan terkait hak atas tanah di Pengadilan Negeri, karena dalam Pengadilan PTUN ini hanya terkait Surat Keputusan terkait penerbitan sertipikat Hak Guna Bangunan yang menjadi obyek sengketa.

\section{Penutup}

\section{A. Kesimpulan}

Berdasarkan uraian dan analisa yang telah penulis sebelumnya, maka Penulis menyimpulkan bahwa sengketa mengenai penerbitan sertipikat Hak Guna Bangunan nomor 2849 ini sangat berkaitan dengan status tanah garapan yang sebenarnya tidak dikenal di dalam Hukum Pertanahan Indonesia, sebelumnya dalam Surat Keputusan Gubernur DKI Jakarta Nomor 353 tahun 1977 tanggal 6 Juni 1977 mengatur dan menegaskan tentang Pencabutan Garapan Tanah Negara tertanggal 6 Juni 1977 bahwa di Wilayah DKI Jakarta sudah tidak dikenal lagi adanya tanah garapan dengan menyatakan tidak berlaku lagi semua bentuk tanda bukti garapan tanah Negara di Wilayah DKI Jakarta. Terlebih dalam kasus ini pihak Penggugat mengajukan tanda bukti akta pengoperan hak yang dalam prakteknya dibuat oleh notaris Surdjono Arham sebagai bukti yang otentik mengenai beralihnya suatu tanah garapan.juga tidak terdapat dalam Hukum Pertanahan Indonesia. Karena alas hak dari suatu tanah garapan yang tidak jelas memicu terjadinya sengketa terkait hak atas suatu tanah. Selain itu dalam proses pendaftaran tanah sengketa ini terdapat kesalahan yang 
seharusnya tidak dilakukan oleh pihak BPN mengenai dikeluarkannya Surat Keputusan Pemberian Hak Guna Bangunan yang lebih cepat 7 hari dari tanggal yang seharusnya diterbitkan pada masa 60 hari setelah hari pengumuman sehingga terdapat cacat prosedural terkait batalnya Keputusan Tata Usaha Negara yang diterbitkan oleh Tergugat berupa Sertipikat Hak Guna Bangunan nomor 2849. Keputusan Hakim untuk mewajibkan Tergugat untuk mencabut sertipikat Hak Guna Bangunan nomor 2849 sudah benar karena telah melanggar asas-asas umum pemerintahan yang baik khususnya asas kepastian hukum, asas tertib penyelenggaraan negara, dan asas profesionalitas. Tetapi yang menjadi pemicu adanya gugatan ini karena adanya pihak yang merasa dirugikan akibat penerbitkan sertipikat tersebut, selain itu peraturan mengenai pertanahan dirasa masih belum lengkap, data yang kurang akurat dan kurang lengkap, pihak.

\section{B. Saran}

Berdasarkan kesimpulan di atas, adapun saran-saran yang dapat diberikan Penulis yaitu agar para pihak yang sudah memiliki suatu tanah baik dengan transaksi jual beli, pewarisan dan lain sebaiknya segera melakukan pendaftaran tanah sesuai ketentuan yang berlaku, apabila obyek tanah tersebut sudah terdaftar sebelumnya maka kemudian dilakukan pemeliharaan data pendaftaran tanah. Kemudian dikarenakan tidak semua pihak dalam Kantor Pertanahan mempunyai pengetahuan yang cukup mengenai Hukum Pertanahan sehingga hal ini dapat menimbulkan cacat administrasi dalam pendaftaran, oleh karena itu sebaiknya diberikan pengetahuan yang mendalam mengenai Hukum Pertanahan kepada para pihak yang ada di Kantor Pertanahan. Sebaiknya pihak dalam Kantor Pertanahan BPN menelusuri lebih lanjut mengenai pengecekan data materil atau data praktek terkait tanah yang sedang dalam proses pendaftaran tanah untuk mengurangi resiko terjadinya kesalahan dalam pencatatan di Buku Tanah. 


\section{DAFTAR PUSTAKA}

\section{A. Buku}

Harsono, Boedi. Hukum Agraria Indonesia. Jakarta: Universitas Trisaksi, 2016.

Ismaya, Samun. Hukum Administrasi Pertanahan. Yogyakarta: Graha Ilmu, 2013.

Santoso, Urip. Hukum Agraria Kajian Komprehensif . Jakarta: Kencana Prenada Media Group, 2013.

\section{B. Peraturan Perundang-Undangan}

Indonesia. Undang-Undang Dasar Negara Indonesia Tahun 1945.

. Undang-Undang Nomor 5 Tahun 1960 Tentang Peraturan

Dasar Pokok-Pokok Agraria (Lembaran Negara Republik Indonesia

Tahun 1960 Nomor 104, Tambahan Lembaran Negara Republik Indonesia Nomor 2043).

Undang-Undang Nomor 5 Tahun 1986 Tentang Peradilan

Tata Usaha Negara (Lembaran Negara Republik Indonesia Tahun 2004 Nomor 35, Tambahan Lembaran Negara Republik Indonesia Nomor 4380).

. Undang-Undang Nomor 9 Tahun 2004 tentang Perubahan atas Undang-Undang Nomor 5 Tahun 1996 tentang Peradilan Tata Usaha Negara (Lembaran Negara Republik Indonesia Tahun 2004 Nomor 3, Tambahan Lembaran Negara Republik Indonesia Nomor 4380). . Undang-Undang Nomor 51 Tahun 2009 tentang Perubahan

Kedua atas Undang-Undang Nomor 5 Tahun 1986 tentang Peradilan Tata Usaha Negara (Lembaran Negara Republik Indonesia Tahun 2009 Nomor 160, Tambahan Lembaran Negara Republik Indonesia Nomor 5079).

. Peraturan Pemerintah Nomor 40 Tahun 1996 tentang Hak Guna Usaha, Hak Guna Bangunan dan Hak Pakai Atas Tanah (Lembaran Negara Republik Tahun 1996 Nomor 58, Tambahan Lembaran Negara Republik Indonesia Nomor 3643).

- Peraturan Pemerintah Nomor 24 Tahun 1997 Tentang Pendaftaran Tanah (Lembaran Negara Republik Tahun 1997 Nomor 59, Tambahan Lembaran Negara Republik Indonesia Nomor 3696).

\section{Jurnal}

Pahlefi. "Analisis Bentuk-Bentuk Sengketa Hukum atas Tanah Menurut Peraturan Perundang-Undangan di Bidang Agraria", Majalah Hukum Forum Akademika, Volume 25, Nomor 1 (Maret 2014): 138.

\section{Artikel Internet}

Syafruddin Kalo. "Aspek dan Impikasi Hukum Dalam Pendaftaran Tanah dan Penertiban Sertipikat atas Tanah," http://www.hukumonline.com/berita/baca/hol19216/aspek-dan-implikasi- 
hukum-dalam-pendaftaran-tanah-dan-penertiban-sertifikat-hakhak-atastanah. Diakses tanggal 4 Juni 2018.

Berbagi Ilmu Hukum, "Hak Primer dan Hak Sekunder Dalam Hukum Agraria," http://e-lawenforcement.blogspot.com/2014/09/hak-primer-danhak-sekunder-dalam-hukum.html. Diakses tanggal 4 Juni 2018. 